\title{
Structure of the Demerara passive-transform margin and associated sedimentary processes. Initial results from the IGUANES cruise
}

\author{
Loncke L. ${ }^{1,}$, , Maillard A. ${ }^{2}$, Basile C. ${ }^{3}$, Roest Walter ${ }^{4}$, Bayon Germain ${ }^{4}$, Gaullier V. ${ }^{5}$, Pattier France ${ }^{1}$, \\ Mercier De Lépinay Marion ${ }^{1}$, Grall Celine ${ }^{1}$, Droz L. ${ }^{6}$, Marsset Tania ${ }^{4}$, Giresse P. ${ }^{1}$, \\ Caprais Jean-Claude ${ }^{4}$, Cathalot Cecile ${ }^{4}$, Graindorge D. ${ }^{6}$, Heuret A. ${ }^{7}$, Lebrun J. F. ${ }^{7}$, Bermell Sylvain ${ }^{4}$, \\ Marcaillou B. ${ }^{7}$, Sotin C. ' ${ }^{1}$, Hebert B. ${ }^{1}$, Patriat Martin ${ }^{4}$, Bassetti M. A. ${ }^{1}$, Tallobre Cedric ${ }^{1}$, Buscail R. ${ }^{1}$, \\ Durrieu De Madron X. ${ }^{1}$, Bourrin F.
}

${ }^{1}$ Université de Perpignan Via Domitia, Centre de Formation et de Recherche sur les Environnements Méditerranéens, UMR 5110, 52 avenue Paul Alduy, F-66860, Perpignan, France

${ }^{2}$ GET-OMP-Université Paul Sabatier, 14 avenue E. Belin, 31400, Toulouse, France

${ }^{3}$ ISTerre, UMR-CNRS 5275, Observatoire des Sciences de I'Univers de Grenoble, Université Joseph Fourier, Maison des Géosciences, 1381 rue de la Piscine, 38400 St Martin d'Hères, France

${ }^{4}$ Ifremer, Centre de Brest, Institut Carnot-Ifremer EDROME, UR Géosciences Marines, BP 70, 29280

Plouzané, France

${ }^{5}$ Université de Lille 1, UMR 8217 - Géosystèmes, Bâtiment S.N.5, Cité Scientifique, 59655 Villeneuve d'Ascq Cedex, France

${ }^{6}$ Université de Bretagne Occidentale (UBO)/UMR 6538 du CNRS 'Domaines Oceaniques', Institut Universitaire Européen de la Mer (IUEM), Technopole Brest Iroise, Place Nicolas Copernic, 29280

Plouzané, France

${ }^{7}$ Université des Antilles et de la Guyane, Laboratoire Large, Campus Fouillole, BP 592, 97157 Pointe à Pitre, France

* Corresponding author : L. Loncke, email address : lies.loncke@univ-perp.fr

\begin{abstract}
:
he IGUANES cruise took place in May 2013 on the R/V L'Atalante along the Demerara passive transform margin off French Guiana and Surinam. Seismic, multibeam and chirp acquisitions were made. Piston cores were collected for pore geochemistry and sedimentology. A mooring was deployed on the sea-bottom for 10 months (temperature, salinity, turbidity and current measurements). This new dataset highlights the lateral variability of the $350 \mathrm{~km}$-long Guiana-Surinam transform margin due to the presence of a releasing bend between two transform segments. The adjacent Demerara Plateau is affected by a $350 \mathrm{~km}$-long giant slide complex. This complex initiated in Cretaceous times and was regularly reactivated until recent times. Since the Miocene, contourite processes seem to be active due to the onset of the North Atlantic Deep Water (NADW) bottom current. A main NADW water vein flows towards SE, eroding slide headscarps and allowing the deposition of contourite drifts. Numerous depressions looking like comet tails or comet scours record this flow. Some of those were interpreted before the cruise as active pockmarks. Pore geochemistry and core analysis do not show any evidence of present-day gas seepage.
\end{abstract}




\section{Introduction:}

Transform margins have been widely investigated in the eighties and late nineties (e.g. Mascle \& Blarez 1987, Mascle et al 1998, Côte d'Ivoire-Ghana transform margin ; Reid 1988, Grand Banks ; Lorenzo et al. 1991, Southern Exmouth plateau ; Lorenzo and Wessel 1997, Falklands/Malvinas transform margin ; Vagnes 1997, Senja transform margin ; Reid \& Jackson 1997, Baffin Bay transform margins ; Ben-Avraham et al. 1997, Agulhas transform margin). Those investigations were the most complete off Côte d'Ivoire and Ghana where geophysical data (seismic reflection and refraction, multibeam bathymetric data) were acquired, and ODP drilling and Nautile dives performed (Mascle et al. 1998). There, the transform margin architecture displays a well-developed marginal ridge along the continent-ocean transition zone. The interpretation of geophysical data, ODP results, and rocks collected by dives allowed to reconstruct the geodynamic evolution for this margin (Basile et al. 1998), including explanations for the marginal ridge formation (Sage et al. 2000 ; Basile \& Allemand 2002). At the time, Côte d'Ivoire-Ghana was the best example to understand transforms margin initiation and evolution. Since, Dailly et al 2012 showed how the structure of the Côte d'Ivoire Ghana margin controls sediment deposition by creating sharp slopes and confining sediments between structural highs (marginal ridge and second order tectonic features). They described and analyzed very attractive stratigraphic traps in post-rift Cretaceous sediments (example of the Jubilee oil field).

However, Côte d'Ivoire-Ghana probably does not reflect the great variability of transform margins, in lengths (from 50 to $1350 \mathrm{~km}$ ), physiographic and structural characteristicset al. Seen the variety of structures than can develop in a dominantly strike-slip regime during continental breakup (transtension, transpression, pure strike-slip), one could infer a great diversity of later margins. For example, marginal ridges do not develop along all transform margins although they are usually considered as a systematic attribute for transform margins (see the examples of Côte d'Ivoire Ghana, Voring, Southern Exmouth - Basile et al. 1993, Berndt et al. 2001, Lorenzo \& Vera 1992). In some places, tilted blocks characterize the transform continent-ocean boundary (example of Western Ivory Coast transform margin, De Caprona 1992 or French Guiana, Basile et al. 2013). Also, recent studies showed that a third of transform margins bound marginal plateaus, i.e. deep submarine plateaus extending the continental shelf down to $3000 \mathrm{~m}$ deep (Mercier et al. in revision). It is the case of the Demerara plateau along the Guiana-Surinam transform margin.

For all these reasons, there is a need in better characterizing structural and sedimentary systems (including fluid migration patterns) along different margins. The Demerara plateau is an interesting target for such an integrative analysis. Indeed, Greenroyd et al. 2007 \& 2008a showed that this plateau is underlain by a $25 \mathrm{~km}$-thick continental crust, probably thinned during the Jurassic Central Atlantic opening, and northward bounded by a narrow ocean-continent transition derived from the Cretaceous transform-dominated equatorial Atlantic opening. Basile et al. 2013 showed that no marginal ridge could be observed, at least in the eastern termination of the transform boundary and that its continental slope was, as along Côte d'Ivoire-Ghana, a steep and non-sedimented domain. The regional structural analysis of Gouyet 1988, comparison with oceanic fracture zones (Greenroyd et al. 2008b), and seismic lines shot to prepare ODP leg 207 off Northwest Demerara (Mosher et al. 2007) all suggest that this $350 \mathrm{~km}$ long transform margin may show an important lateral variability. Recent studies show also that sedimentation is dominated by mass- 
wasting processes and that active fluid escape structures may be present on the Demerara plateau seafloor (Loncke et al. 2009; Pattier et al. 2013).

In order to better characterize this transform margin structure and sedimentary dynamics, the University of Perpignan (CEFREM - UMR5110) and Ifremer organized the multidisciplinary IGUANES cruise along the Demerara plateau off French Guiana and Surinam. It occurred on the R/V L'Atalante in May 2013. The purpose of the scientific cruise was the investigation of the lateral variability of the $350 \mathrm{~km}$ long Demerara passive transform margin and to study associated sediment processes and fluid escape structures. This paper presents the newly acquired dataset and discusses those new findings.

\section{Geological setting}

The Demerara transform margin bounds a deep-sea plateau (Demerara plateau) (Fig. 1) that developed in two stages. Its western edge formed in the Jurassic times during the divergent opening of the Central Atlantic (Klitgord \& Schouten 1986; Gouyet 1988; Unternehr et al. 1988). Its northern and eastern edges were structured in the Late Cretaceous, during the opening of the Equatorial Atlantic in a transform mode (Fig. 1) (Gouyet, 1988; Unternerhr et al. 1988; Greenroyd et al. 2008a \& b). The northern edge of the Demerara plateau is a passive transform margin. Its eastern edge formed in a divergent mode at the same time and corresponds to a divergent passive margin segment. The Demerara plateau is an outstanding relief $160 \mathrm{~km}$-wide and $350 \mathrm{~km}$-long, ranging from 200 to $3800 \mathrm{~m}$ water depth. Seismic refraction data acquired across the plateau perpendicular to the transform margin (Greenroyd et al. $2007 \&$ 2008a) suggest that it is made of thinned continental crust. Its northern border is characterized by a narrow necking zone (Greenroyd et al. 2008) typical for transform continent to ocean transitions (Sage et al. 2000; Harry et al. 2013).

The Demerara plateau is located between the Amazon deep-sea fan to the southeast and the Orinoco fan to the west (Fig. 1). Its elevated position probably prevents any significant accumulation from those two sediment sources. However, the Guiana coast is characterized by a muddy northwestward longshore drift. Mud banks are fed mainly by the Amazon River outwash plume (Pujos \& Froidefond 1995). During the retroflection phenomenon of the North Brazil Current, pelagic suspension seasonally invades the continental shelf (Pujos \& Froidefond 1995). In turn, the Maroni River is well-positioned to feed this plateau.

A regional seismic data analysis (Gouyet 1988) revealed a post-Albian sedimentary basin resting on the Demerara plateau. It has the shape of a thick prograding sedimentary wedge with a maximum thickness of $4 \mathrm{~km}$ under the shelf (Fig. 2). This wedge is progressively thinning seaward: the external parts of the plateau are considered to be sediment starved at present (Mosher et al. 2007; Pattier et al. 2013). Below an upper Albian unconformity, a thick wedge of sediments exists whose basal boundary is difficult to assess due to limited seismic penetration (Fig. 2). The upper Albian unconformity has been drilled (Gouyet 1988; Mosher et al. 2007). It corresponds to a sub-aerial erosive surface covered by shell debris. Upper Cretaceous sediments then record a major transgression, with deposition of Cenomanian-Turonian black shales. Sedimentation is detritic up to the Paleocene. Then, argillaceous chalks and ooze dominate until the Miocene. The Pliocene is marked by onset 
of Amazon (and probably Maroni) terrigeneous derived sediments (clays) (Gouyet 1988; Mosher et al. 2007).

The analysis of a data acquired in the framework of extension of the French continental shelf in the framework of the UN Convention on the Law of the Sea (GUYAPLAC survey, 2003) showed that the outer Demerara plateau was affected by numerous submarine landslides. These landslides cut back retrogressively from the transform-derived continental slope to more than $80 \mathrm{~km}$ landward (Loncke et al. 2009; Gaullier et al. 2010; Pattier et al. 2013). Numerous elongated seafloor depressions were also recognized on the top of the destabilized complex. They have been interpreted as pockmarks elongated by strong deep-sea currents (Loncke et al. 2009; Pattier et al. 2013). This domain, between 2500 and $4300 \mathrm{~m}$ water depth, is the location of the southeastward flowing North Atlantic Deep Water (NADW) water mass (Johns et al. 1993). Pattier et al. 2013 proposed that the steepness of the transform margin, associated with fluid overpressure at depth, could have been the main factors controlling recurrent slope instability.

\section{Dataset and methods}

A new dataset has been acquired in May 2013 along the Demerara passive transform margin off French Guiana and Surinam on board the R/V L'Atalante. The IGUANES campaign was conducted by the University of Perpignan (CEFREM, UMR 5110) and Ifremer. The new dataset comprises:

- EM122 multibeam echosounder data (bathymetry, backscatter imagery and water column) and chirp data.

- A 24 channel seismic reflection grid with a series of regional lines mainly acquired perpendicular to the transform margin (acquisition speed $\sim 8$ knots). (Fig. 3).

- A 72 channel high-resolution seismic reflection grid focusing on the main destabilized complex already defined before the cruise (Loncke et al. 2009; Pattier et al. 2013) (acquisition speed $\sim 5$ knots). A collection of 20 piston-cores, mostly placed within the seafloor depressions interpreted before the cruise as pockmarks (Loncke et al. 2009; Pattier et al. 2013). Those cores were dedicated to geochemistry, heatflow measurements and sedimentology.

- A mooring was emplaced at 3000 m depth off French Guiana on the Demerara plateau. It was equipped with an Anderaa RCM8 current meter, a RBR virtuoso turbidimeter, and a microcat SBE37 SMP pressure, temperature and conductivity sensor (CTD). This mooring was recovered in March 2014 providing a 10 month long hydrological record (temperature and derived salinity, turbidity, and current measurements). This dataset will be analyzed to estimate sediment transport capacity and related to bottom sediment features.

Seismic data were processed using the Ifremer QC-Sispeed software. First, a quality control of navigation and seismic data was performed. Then, SEGD data were converted to SEGY and binning, stack and migration were performed. The maximum vertical resolution of seismic data is $10 \mathrm{~m}$ for the 24 channel acquisition and $4 \mathrm{~m}$ for the high resolution 72 channel acquisition. The sub bottom profiler data (SBP, chirp mode, band width 1800-5300 $\mathrm{Hz}$ ) were processed (quality control and concatenation) using the Ifremer Subop software. The profiles have an average vertical resolution of 20 to $30 \mathrm{~cm}$ and a horizontal resolution 
of $20 \mathrm{~m}$ (500 m water depth) to $60 \mathrm{~m}$ (4000 m water depth). Multibeam data were processed using the Ifremer Caraibes software. Abnormal bathymetric soundings were removed. The raw data have been filtered and interpolated allowing construction of a 25 $\mathrm{m}$ resolution grid. Slope gradients were calculated on the basis of this grid. Imagery was processed by deleting abnormal bathymetric records and interpolating the data. A $10 \mathrm{~m}$ resolution grid was obtained. All these data were integrated in Q-GIS software for comparison and analysis. All maps have been projected in UTM zone 22 in WGS84 geodetic system.

Free-air gravity anomalies derived from global satellite altimetric data (Sandwell \& Smith 2009 \& Sandwell et al. 2014), were re-evaluated in order to give supplemental information about the track of the northern oceanic-continental boundary of the plateau and the structure of the plateau. Residual gravimetric anomalies were estimated by correcting the free-air gravity anomalies to the gravity anomalies associated to the sediment/sea-water interface. The gravimetric anomalies of this density interface have been computed over a shipboard bathymetric grid covering an area of 800 by $900 \mathrm{~km}$ (centred on the plateau) with a resolution of 150 by $150 \mathrm{~m}$. This grid has been obtained by combining multibeam data acquired during GEBCO and GUYAPLAC cruises. The gravimetric contribution of the sediment/seawater interface have been computed by using the Parker Formulation of the gravimetric correction of density interfaces (Parker et al. 1973; Harmon et al. 2007), and considering a density contrast of $0.625 \mathrm{~kg} / \mathrm{m}^{3}$ at the sediment/sea-water interface.

Finally, piston cores were collected during the cruise for the geochemical analysis of porewaters and sedimentology. Upon recovery, cores in their liner were divided into one meter sections that were numbered serially from the top. As soon as a 1-m core section was retrieved, $\mathrm{pH}$ and redox measurements were performed at 10 and $90 \mathrm{~cm}$ using Metrohm electrodes. Every other $10 \mathrm{~cm}$ along the core section, porefluid samples were taken. Briefly, porewaters were extracted using a Rhizon system. They were vacuumed and filtered through porous ceramic tubes attached to syringes. A detailed description of the method is available in Seeberg-Elverfeldt et al 2005. Immediately after pore-water extraction, porewater samples were conditioned for further laboratory analysis. At 20 and $60 \mathrm{~cm}$, a volume of $5 \mathrm{ml}$ was stored in a $\mathrm{N}_{2}$ flushed flask for the determination of methane concentration by GC-FID. At 30 and $70 \mathrm{~cm}$, a volume of $1 \mathrm{ml}$ was stored in a vacuum flask, (in which $1 \mathrm{ml}$ of $\mathrm{ZnCl}_{2}$ was added) for the determination of total sulfides back in the lab, 1 $\mathrm{ml}$ was stored in as Eppendorf vial for direct measurement of total alkalinity (Methrom titrator), and the remaining porewater sample was acidified $\left(0.02 \% \mathrm{HNO}_{3}\right)$ and stored for later analysis of $\mathrm{Cl}$ - and $\mathrm{SO}_{4}{ }^{2-}$ ions (using ion chromatography). Finally at 40 and $80 \mathrm{~cm}$, porewater samples were stored for carbonate and ICP-MS analysis. The cores were then opened and described in the sedimentology laboratory of Ifremer in Brest in December 2013 and February 2014.

\section{Results}

\section{Structure of the Guiana-Transform transform margin}

The Demerara plateau (Fig. 4) reaches water depths of 1200 to $2400 \mathrm{~m}$. To the north, the boundary between the plateau and the continental slope follows more or less the $1400 \mathrm{~m}$ isobath. The downslope limit of the continental slope and its transition with the abyssal 
plain lies at depths between 4400 and $4700 \mathrm{~m}$, the deepest area being at the northeastern corner of the plateau. Eastward, the $1400 \mathrm{~m}$ isobath separates the sub-horizontal upper Plateau and an intermediate plateau (defined in Basile et al. 2013), gently dipping northeastward down to $3500 \mathrm{~m}$ toward the abyssal plain lying at $4700 \mathrm{~m}$ (northward) and $4200 \mathrm{~m}$ depth (south-westward) (Fig. 4). Steep continental slopes are observed along the northwestern corner (up to $26^{\circ}$ on average) and in two areas of the north-eastern corner (up to $41^{\circ}$ on average). In the central and eastern parts, the continental slope is more gentle $\left(<10^{\circ}\right.$ on average).

On seismic lines, the most striking feature of the deep structure of the plateau is a late Albian angular unconformity (Fig. 5). This prominent erosional surface is the boundary between folded, tilted and faulted Lower Cretaceous to Jurassic sediments and subhorizontal or seaward tilted overlying sediments (Fig. 5). The erosional surface is interpreted as wave-cut, initially sub-horizontal. Actually, it has a convex shape, dipping northward, down to a slope break beneath the continental slope at a remarkably constant depth of 4.2 seconds two way travel time (Fig. 5). The overlying sedimentary layers parallel the unconformity, and have the same dip. They localise gravity-driven slides (cf. next section). The best expressed sliding scarp follows the $1400 \mathrm{~m}$ isobaths in the northern part, and is slightly deeper (1600-1800 m) further to the east (Fig. 4). In the abyssal plain, we interpret the northernmost part of the seismic lines as an oceanic crust covered by a thick sedimentary section, fed from the west by the Orinoco deep-sea fan, from the east by the Amazon deep-sea fan, and from the south by gravity-driven collapses from the edge of the Demerara plateau (Fig. 5). We defined the ocean-continent boundary from the comparison of gravimetric and seismic data. The boundary between the oceanic and the continental domains is delineated by the transition between positive residual gravimetric anomalies (thin oceanic crust, Fig. 6) and negative residual gravimetric anomalies (thicker continental crust, Fig. 6). On seismic profiles, the southern edge of the oceanic crust lies below the abyssal plain, and corresponds either to the bottom of the continental basement slope (lines 109 and 121 Fig. 5), or to the seaward boundary of faulted blocks (lines 114 and 119 Fig. 5). This oceanic crust bounds a 10 to $50 \mathrm{~km}$-wide continent-ocean transition zone below the continental slope.

Three domains can be defined along the northern edge of the plateau by different characteristics (Fig. 6):

Domain A: In the north-western corner of the Demerara plateau, the ocean-continent transition zone is narrow (10 to $15 \mathrm{~km}$ wide) and fits with the linear, steep and eroded continental slope. The transition is unfortunately not visible as it should on seismic line 109 (Fig. 5). Indeed, this line passes near an irregularity of the continental slope visible in Figure 4. This irregularity is responsible for an important lateral echo looking as a crustal block with slightly bedded series. The ocean boundary is clear on gravimetry data, underlined by a positive anomaly. It is linear, NE-SW oriented. On seismic profiles, it corresponds to the trench located at the bottom of the continental slope, beneath the sediments of the abyssal plain (line 109, Fig. 5). The oceanic boundary is lined up with an oceanic fracture zone (Fig. 6), suggesting that it is a former dextral transform fault. In this area, there is no typical marginal ridge, but rather a slight seaward flexure of the Late Albian erosional surface approaching the oceanic domain (Fig. 5).

Domain B: In the central part, the ocean to continent transition zone widens from 15 to 50 
$\mathrm{km}$ and its deep structure changes. On gravimetry, this domain is well-correlated with a sigmoid-shape zone characterized by low negative residual gravimetric anomalies (Fig. 6). The central part of this sigmoid-shape zone trends $40^{\circ}$ relatively to the oceanic fracture zones (Fig. 6).

On seismic lines 114 and 119, the transition zone is associated with 5 to $25 \mathrm{~km}$ wide tilted blocks. The top of the blocks have strata tilted southward (toward the plateau), and truncated by a planar erosional surface (lines 114 and 119, Fig. 5). As there are no stratigraphic constrains in this area, the age of this unconformity is unknown. It may corresponds to the late Albian unconformity observed and dated on the continental plateau. Above those tilted blocks, recent strata are clearly destabilized (see failure scars and mega-slides located in the slope domain, Fig. 5). The continental slope is less steep than in domain $\mathrm{A}$.

The configuration of the gravimetric anomaly and the observed deformations associated with this zone are consistent with transtensive faulting in a releasing stepover. However, the block faulting may have occurred after active transform deformation. Because of the limited depth penetration of the seismic acquisition systems used on the IGUANES cruise, this question cannot be solved with the available data.

Domain C: In the north-eastern corner of the Plateau, the ocean-continent transition zone is more difficult to map using gravimetry solely (Fig. 6). On line 121 (Fig. 5), this transition is very narrow $(15 \mathrm{~km})$, made of one prominent acoustic basement ridge. This ridge is quite similar in shape to the ridges observed in oceanic transform faults or along some transform margins (e.g. Côte d'Ivoire Ghana transform margin, Basile et al. 1998, southern Voring margin, Berndt et al. 2001). The nature of this ridge is unknown. It is a transparent acoustic body with no visible internal strata. The acoustic basement ridge observed on seismic data correlates with the distal tip of a NW-SE positive residual gravity anomaly (Fig. 6). A series of left-lateral en echelon acoustic basement ridges (mapped from this study and Basile et al. 2013) correlated with positive residual gravity anomalies occur in domain $\mathrm{C}$ ocean to continent transition (Fig. 6). The zone containing the ridges parallels the fracture zones, but the ridges are aligned $20^{\circ}$ clockwise from this trend (Fig. 7). They may be interpreted as Riedel shears rather than en echelon folds that would have a rightlateral en echelon orientation given the overall dextral strike-slip displacement between Africa and South America. Going East, NNW-SSE acoustic basement Ridges have been mapped in Basile et al. 2013. This rotation may be related to the proximity of the plate divergent margin. The continental slope is very steep and eroded in the westernmost domain C (line 121, Fig. 5) and is gentler going east. Recent sediments are affected by instabilities that initiate far inland (Line 121, Fig. 5). When present, basement acoustic ridges seem to act as distal dams preventing remobilized sediments to overlay the continental slope and fall into the abyssal plain (line 121, Fig. 5).

\section{Prevalence of slope instability}

Another important result of the IGUANES cruise is the discovery of a giant slide complex along the entire margin of the Demerara plateau. The eastern third of this complex was already defined before the cruise (Loncke et al. 2009; Pattier et al. 2013). This complex is expressed by a $350 \mathrm{~km}$ long slope failure headscarp, visible in bathymetry (Fig. 4). Slope failure occurs in water depths between $1400 \mathrm{~m}$ (to the NW) and $1800 \mathrm{~m}$ (to the SE). In domains $\mathrm{A}$ and $\mathrm{B}$, the main headscarp parallels the transform continent-ocean transition 
zone (Figs 4-6). In domain C, approaching the eastern Demerara divergent border, the upper limit of the slide complex diverges from the trend of the transform ocean continent transition by $40^{\circ}$. The slide complex reaches the abyssal plain but its total length could not be observed in domains A and B. In domain C, better imaged with the IGUANES dataset, the complex is at least $115 \mathrm{~km}$ in length.

This slide complex displaces post-transform strata, from Cretaceous to recent ages. It comprises several stacked slump masses and associated mass-transport deposits whose approximate age and retrogressive evolution has been described by Pattier et al. 2013 for the eastern part. In domains $A$ and $B$, most of the complex is characterized by coherent slide blocks. The upper part of the complex is characterized by imbricated normal faults (Fig. 7). The destabilized body passes laterally to a chaotic to transparent acoustic mass whose distal tip is intercalated within abyssal plain sediments (Fig. 5). In domain C, only the main headscarp is visible. Destabilized strata are deformed and remobilized, near the headscarp and downward, clearly mass-transport deposits. Those bodies are acoustically transparent or chaotic and their thickness generally increases distally. It is sometimes difficult to map the continuity of those bodies down to the abyssal plain because of the presence of basement acoustic ridges that form local dams for mass-wasting deposits and of the very steep continental slope which is not sedimented (Fig. 5).

\section{Numerous elongated seafloor depressions}

Hundreds of elongated depressions have been observed on the seafloor, with a higher bathymetric resolution due to the IGUANES $25 \mathrm{~m}$-grid survey, as opposed to the older GUYAPLAC 150 m-grid (see Fig. 8). The depressions appear only on top the destabilized domain of the Demerara plateau. On the basis of the new data-set, most depressions look like giant flute casts elongated south-eastwards. The depressions occur in seven principal clusters (Fig. 9). Some of these clusters appear as giant flute casts alignments (e.g Tangara, Matoutou, Jamais-Goûté, Acoupa fields in Fig. 9), others as randomly distributed depression clusters (e.g Pacou, La Belle Cabresse, Maman di lo fields in Fig. 9). When aligned, the depressions trend NE-SW in the north and E-W in the south. The alignments follow dip of the main slope.

There is also a great variety in the shape of the depressions. Type A depressions, the most numerous look as scour marks or comet tails, i.e obstacle-induced long erosional strips occurring on current-affected sea bottoms (Flemming, 1980, Werner et al. 1980, Kuijpers et al. 1993, Rebesco et al. 2014), (Fig. 10). Type A depressions, first defined by Pattier et al. 2013 are the largest. They have an average width of $540 \mathrm{~m}$, ranging from $100 \mathrm{~m}$ to 2 $\mathrm{km}$. Their lengths are $1,4 \mathrm{~km}$ on average, ranging from $100 \mathrm{~m}$ to $10 \mathrm{~km}$. Their depths vary from 5 to $90 \mathrm{~m}$. In most cases, the depressions have sharp boundaries. Sometimes, the head of the comet appears in bathymetry as a rough hummocky domain, possibly indicating exhumation of underlying structure by the deep currents (Fig. 10A). Bathymetric and seismic highs are observed at the northwestern edge of numerous comet tails (Fig. 10A and $B)$. These features then look like scour marks around obstacles. Type B depressions are sub-circular (first defined by Pattier et al., 2013) (Fig. 10C). Type B depressions are the smallest, averaging $340 \mathrm{~m}$ in diameter. They are located in rather flat bathymetric domains devoid of any outcropping highs on seismic data. They look like pockmarks on 
chirp profiles (see Pattier et al. 2013). Finally, some depressions appear as deep gullies associated with areas of steeper seabed gradient. They look like pockmark trains described by Pilcher and Argent (2007) as deriving from interaction between slope failure and fluid escape structures.

High-resolution seismic profiles show that type A depressions occur above shallow acoustically transparent sediments that could be stacked mass-transport deposits, gravity slide blocks (Figs 11B-D). In seismic lines, normal faults are present below the depression clusters. Pattier et al. 2013 proposed that deep thermogenic, biogenic (microbial) or diagenetic fluids may have been expelled through time along these faults and were responsible for the depressions (in this case, pockmarks), subsequently elongated by deep bottom currents. On some seismic profiles, acoustically chaotic mounds are observed under the depression fields (Figs 11A-C). They could correspond to mass-transported blocks, carbonate authigenic mounds or coral mounds. In the hypothesis of coral mounds, they would develop in association with strong bottom currents as observed along Porcupine slope for example (Van Rooij et al. 2003). In the hypothesis of authigenic mounds, they could be fed by mass-transport deposit dewatering or deeper biogenic or thermogenic sources. However, the cores taken on such a feature (KS11 and 09, Fig. 11A) show no evidence of fluid-derived authigenic rocks or interstitial fluid anomalies. These short cores (6.0 and $3.23 \mathrm{~m}$ respectively), likely sampled recent sediments (grey foraminifera rich siltstones) covering the mound, not the mound itself.

Piston-cores have been collected within the depressions (Fig. 12). The recovery length varies between $50 \mathrm{~cm}$ to $10 \mathrm{~m}$ according to the lithology. Most of the cores contain grey to greenish silty muds. Sparse bioclasts are present in the argillaceous matrix represented by foraminifera, pteropods, other gastropods, ostracods, sponges, sea-urchins and bivalves. Remobilized debris flows made of calcareous mudstones have been recovered in some cores, for example from those in the La belle Cabresse and Tangara fields (KS01 Fig. 12D and KS13, Fig. 12C). Those cores were extremely dry, suggesting that fluids have been expelled by dewatering or that those series have been strongly eroded. Measured concentrations of total alkalinity and methane in pore fluids have been performed on almost all cores. Their total alkalinity ranges from seawater values (i.e. $2.2 \mathrm{mM}$ ) to about $14 \mathrm{mM}$ at the base of the downslope reference core IG-KSF-02. Amongst all studied cores, IG-KSF-02 abyssal plain reference core displays the highest alkalinity gradient $(\sim 1.6$ $\mathrm{mM} / \mathrm{m})$. In comparison, the cores recovered at the Matoutou depression cluster exhibit lower gradients (average $0.4 \pm 0.2 \mathrm{mM} / \mathrm{m}$ ), similar to that from the upper slope reference core (IG-KSF-19; $0.5 \mathrm{mM} / \mathrm{m})$. Interestingly, all the cores from the other depression clusters (i.e. Pacou, Acoupa, La Belle Cabresse, Tangara) were characterized by near-zero alkalinity gradients. With the exception of the two discrete samples from the abyssal plain reference core IG-KSF-02 (3.1 and $4.1 \mu \mathrm{M} / \mathrm{l})$, methane concentrations were similar to the background pore water values for typical sub-surface sediments at ocean margins (i.e. $1.2 \pm 0.3 \mu \mathrm{M} /$ l). Therefore, the sampled depressions, if they are pockmarks, are no longer active at present or are water-driven.

\section{Contourites}

The southeast elongation of all observed depressions, either "comet tails" or "comet scours" around obstacles suggest that a deep bottom current is involved in sedimentation 
on the margins of the Demerara plateau. Numerous sedimentary ridges occur on the Demerara plateau near the depression fields (Fig. 10). They are mostly oriented NW-SE and look like sediment waves (Fig. 12, detail B). Sea bottom current and temperature-salinity records (May 2013-March 2014) confirm the prevalence of southeast oriented near-bottom current having maximum velocities of $30 \mathrm{~cm} / \mathrm{s}$, a velocity characteristic of the North Atlantic Deep Water current (NADW). The location of mooring is shown in Figure 3.

There is evidence of contourites on the Demerara plateau. The profile presented in Fig. 13 focuses on the main destabilized complex failure headscarp. This line shows that the main failure headscarp is in fact buried, which most likely indicates that it is no more active, at least at a regional scale. Pattier et al. 2013 proposed that the last major instability episode associated with this headscarp occurred at mid Miocene (R1 yellow reflector). Above the mid Miocene headscarp, several reflectors are truncated ( $\mathrm{t} 1$ to t5 on Fig. 13A). Those truncations have been interpreted before the cruise, on lower resolution data, as slide headscarps (Pattier et al. 2013). Truncation 5 looks like an incision and could be a contourite moat (Rebesco et al. 2014). Most of the successive truncations migrate upslope through time. Despite these truncations, the main Pliocene reflectors could be followed or correlated on each side of them. It appears that each main truncation is associated with a downslope mounded elongate drift, e.g, a contourite body thinning distally (see Rebesco et al. 2014 for complete review about contourite processes). Drift 1 and 2 emplace above mass-transport deposits, thin distally and are interrupted by sub-vertical depressions interpreted as fossil pockmarks. There is then a change in drift morphologies from drift 3 to drift 5: they thin distally and upslope migrating sediment waves develop above the subvertical pockmarks (Fig. 13B). The underlying pockmarks seem to have localized the first sediment waves then migrating upslope (Fig. 13B).

\section{Interpretation and discussion}

Based on new observations, we interpret the northernwestern and northeastern edges of the Demerara Plateau (domains $\mathrm{A}$ and $\mathrm{C}$ ) as pure transform margins characterized by a sharp continent-ocean transition, while domain $\mathrm{B}$ corresponds to a transtensional bend between those two transform segments.

In domain A, the ocean boundary parallels the main oceanic fracture zones observed in bathymetry and gravimetry (Fig. 6).

In domain $B$, the ocean to continent transition is wider, correlating with a sigmoid-shape highly negative residual gravity anomaly (Fig. 6). There, a series of quite narrow blocks (5 to $25 \mathrm{~km}$ wide) with continentward dipping strata (Fig. 5) may be interpreted as tilted blocks emplaced in a transtensional bend. This domain, and in particular the ocean boundary, are oblique with respect to the oceanic fracture zones (Fig. 6).

In domain $\mathrm{C}$, the ocean to continent transition is narrow, at least in its westernmost part (Fig. 5). It is made of a series of en echelon acoustic basement ridges whose nature is unknown (deformed cratonic rocks? Deformed Jurassic to Cretaceous sediments? Volcanic syn-rift rocks?). Seen their orientation, those may be interpreted as Riedel shears (Fig. 6). The ocean boundary parallels the oceanic fracture zones (Fig. 6). The easternmost basement acoustic ridges progressively rotate clockwise towards the divergent margin that 
bounds the easternmost Demerara plateau. In parallel, the late Albian unconformity is progressively deepening from southwest to northeast, probably in association with eastwards crustal thinning (Greenroyd et al. 2008; Basile et al. 2013). We interpret domain $\mathrm{C}$ as a transform continental margin and its connection with the southeastward plate divergent margin.

This organization has consequences on post-transform sedimentation patterns: in domain $B$, the continental slope is wider than in other domains and post-transform sediments are thicker above tilted fault blocks. Mega-slides can be followed along the slope (Fig. 5). In the transform segments, the continental slope has not accumulated sediments but rather has been subjected to submarine erosion. Pre-transform rocks crop out and acoustic basement ridges act as dams for continental sedimentation towards the abyssal plain.

One of the goals of this study was to better document the variability in transform margin structure by surveying a $350 \mathrm{~km}$ long transform margin that was likely showing contrasted ocean to continent transitions (Gouyet 1988; Mosher et al. 2007; Basile et al. 2013). Our regional approach allow demonstrating that this margin is made of three structural domains that explain its lateral variability: from west to east, a transform margin, a releasing step over, and a second transform domain progressively turning to a divergent system.

Acoustic basement ridges only exist in domain C. They occur as off Côte d'Ivoire-Ghana near transform to divergent transitions along thinned continental crust domains (Sage et al. 2000; Greenroyd et al. 2007 \& 2008a). The observed acoustic basement ridges have a maximum length of $50 \mathrm{~km}$ and they organize in an en echelon pattern. Their organization may suggest a relation with wrench tectonics in a strike slip regime. However their nature is unknown. Sampling would be needed (via dives, dredging, or drilling) to really compare both features. We are not sure at this stage that they result from the same process than in Côte d'Ivoire-Ghana.

A second observation is that remnants of a releasing bend can be preserved along the ocean to continental transition. It is the case of domain $B$ where the ocean to continental transition is characterized by a series of narrow continental tilted blocks. This may be compared to the western Ivory coast transform margin (DeCaprona 1992).

Finally, as stated by Mercier de Lépinay (Mercier de Lépinay in revision), one third of transform margins bound a marginal plateau i.e a deep submarine plateau prolonging the continental shelf up to $3000 \mathrm{~m}$ deep. It is the case of the French-Guiana-Surinam and Guinean conjugated plateaus. There is no such marginal plateau off Côte d'Ivoire Ghana and turbiditic systems forming interesting reservoirs have been described along the continental slope on the sides of the marginal ridge (Dailly et al. 2012). Off Demerara plateau, no turbiditic pathways could be observed on the slope, probably due intense slope instability and mainly because continental sources are too far (300 km between the coastline and the continental slope). Therefore, turbiditic pathways, if they exist, may have to be searched near the shelf break and depositional lobes may be large and unconfined, the exact opposite of the Côte d'Ivoire Ghana's case (Dailly et al. 2012).

Our observations show also that post-transform strata are displaced by a major slide complex that initiated in Cretaceous time (Pattier et al. 2013) and developed retrogressively on the Demerara plateau from the steep transform-derived continental slope. The main failure headscarp of the recent complex parallels the main slope direction 
derived from complex interplays in between transform and divergent segments. One of the last major gravitational events occurred in the mid-Miocene, in a key period when glacial/interglacial climatic systems were initiated (Seranne, 1999; Ingram et al. 2011). At this time, deep and intermediate currents reorganized and intensified (Muller et al. 1991; Flower \& Kennet 1994; Larsen et al. 1994; Moran et al. 2006). This study shows that Pliocene sedimentation is dominated by contourite processes. The North Atlantic Deep Water (NADW) seems to have followed the main Miocene failure headscarp that possibly formed a bathymetric guide for deep currents (Fig. 13). Subsequently, repetitive truncations or moats and associated mounded elongate drifts recorded the contourite processes associated with the North Atlantic Deep Water. Small-scale mass-transport deposits intercalate within those drifts and the shape of the main slope failure headscarp seems to be maintained in bathymetry and regularly reactivated until now thanks to the contourite processes. Post-Miocene pockmarks, now starved, are observed in the contourite depositional system, in particular within the elongated drifts (Fig. 13B). They may relate to dewatering of underlying mass-transport deposits and drifts or to microbial gas stored in contourites. In any case, they seem to help in localizing later sediment waves in the distal domains of contourite drifts. Finally, numerous elongated depressions characterize the seafloor. They are nowadays still altered by the along-slope North Atlantic deep water flow that exhibits near bottom velocities up to $30 \mathrm{~cm} / \mathrm{s}$. Most of depressions occur at the top of mass transport deposits. Their origin is still a matter of debate. Some of them most probably correspond to comet scours developed down-current of compacted blocks transported by slope instability. Others may relate to pockmarks elongated by currents (Pattier et al. 2013).

\section{Conclusions}

This paper presents some preliminary results of the IGUANES cruise, which is probably the first regional and high resolution multidisciplinary academic campaign dedicated to transform margin. It shows that the $350 \mathrm{~km}$-long Surinam/Guiana transform margin bounding the Demerara plateau displays a lateral variation that reflects a transtensional bend between two transform segments. Acoustic basement ridges are observed along one of the two transform segments at the continental crust edge. There, the continental slope is steep, dominated by erosional processes. Pre-transform rocks crop out along the continental slope. The transtensional relay is sigmoidal in shape and characterized by small tilted blocks. There, the continental slope is smoother, sedimented mostly by posttransform mass-wasting deposits. We believe that this variability directly derives from the intracontinental transform stage (Mascle \& Basile 1998) during which pure strike-slip, transtensional and transpressional bends can occur, especially along a $350 \mathrm{~km}$ long transform.

The pure strike slip segments display some similarities with the Côte d'Ivoire Ghana margin, showing a narrow ocean to continent transition, and in some places en echelon acoustic basement ridges that resemble to the Côte d'Ivoire Ghana marginal ridge at a smaller scale. The nature of the Demerara ridges being unknown and sampling would be needed to state on the processes at the origin with these features (Thermal? Tectonic? Flexural?). 
Another result is the prevalence of slope instability near the transform continent-ocean transition despite low sedimentation rates. No turbiditic pathways have been recognized along the slope, probably because of important distance from the continental sources. The slope instability is recurrent since Cretaceous times (Pattier et al. 2013). It is probably controlled by the specific architecture of the transform border (post-transform sediments "hanging" on the continental slope that has a free interface on the oceanic side) and the steepness of the continental slope (see Pattier et al. 2013 for more discussion). Another important factor, at least since the icehouse period began, seems to be the onset of strong bottom currents such as the one associated with the North Atlantic deep water. Those currents participate to the regular reactivation of the main failure headscarp and allow the development of a contourite depositional system on the Demerara plateau. Finally, active fluid releases were suspected before the cruise, based on geophysical data interpretation. Our first geochemical and sedimentological results from cores focused on interstitial fluids and sediments do not show any evidence of present perturbations related to biogenic or thermogenic fluid ascents. However, pockmarks are visible in depth on high resolution seismic profiles. Those pockmarks may relate to mass transport deposit dewatering or to microbial gases. Deeper thermogenic contaminations are possible since a lot of compactional faults affect the post-transform sediments. Those aspects have to be further investigated.

\section{Acknowledgments:}

We deeply thank the R/V Atalante crew and captain as well as the Genavir geophysics team for the perfect conditions in which the IGUANES acquisitions could be done. We deeply thank Stéphane Kunesch and Marc Vanhaesebroucke for their participation to the IGUANES data processing. A lot of students for the University of Perpignan have worked on this newly acquired dataset and we would like to thank especially Simon Faye, Mirjam Randla, Manon Gourdon, Sarah Lakièvre, Aurélien Marie and Tiphaine Riou. We also thank Gaye Bayracki for stimulating discussions about gravimetric modelling. We are grateful to George Gibson, Steven Schamel and Michal Nemcok for their helpful reviews, corrections and advices. We finally thank Action Marges for supporting this program and Shell for supporting four days of sampling within the IGUANES cruise.

\section{Figure captions}

Figure 1: General map of the study area with main rivers (map from GeoMapApp application, http://www.geomapapp.org). Bathymetric grid is from Ryan et al. 2009. Black arrows indicate transform margins.

Figure 2: Interpretative geological cross-section off the Guiana margin, redrawn from Gouyet (1988).

Figure 3: Position plan of IGUANES acquisitions.

Figure 4: Bathymetry of the Demerara plateau domain. High resolution bathymetric data derives from the IGUANES (dense colors) and GUYAPLAC (light colors) cruises, isobaths from the Etopo 1 grid (Amante and Eakins, 2009). The seismic lines discussed in Figures 5, 711 and 13 are located. The upper and distal boundaries of the slide complex discussed in section 2 are indicated. 
Figure 5: Interpretation of four 24 traces seismic lines crossing the transform-derived Northern Demerara continental slope. See Figure 4 for location of seismic lines. The block located at the bottom of the continental slope on line 109 is a lateral reflection on a small apron more or less parallel with the seismic line.

Figure 6: Residual free-air gravimetric anomalies, corrected of the topographic effect, and main structures recognized on IGUANES and GUYAPLAC seismic data. Bathymetric contours are shown to illustrate the current seafloor topography. Fracture zones (solid blue) come from magnetic anomalies (Greenroyd et al. 2008b). The oceanic crust boundary is localized according to gravimetric data (residual anomalies \pm 5 mgal at the transition) and seismic data. The domains A/B/C defined by seismic analysis are localized. Note the negative gravimetric anomalies observed within the domain $B$ characterized by tilted blocks. The deformation within this zone of the plateau appears associated to the bend between two dextral northeast and northwest transform segments (thick red solid lines).

Figure 7: Detail on line 114 located in Figures 4 and 5. This detail focuses on the upper normal faults that define the slide complex in zone $B$.

Figure 8: Comparison of the resolution between EM12 GUYAPLAC and EM122 IGUANES multibeam bathymetric data.

Figure 9: Bathymetric grid of the high-resolution seismic acquisition domain off French Guiana (EM122). The depression fields discussed in the text are labelled.

Figure 10: Details on Tangara, Matoutou and La belle Cabresse depression fields. Location of cores is indicated.

Figure 11: High-resolution 72 TR seismic line showing that comet tail alignments occur on top of isolated transparent to chaotic seismic units. MTD: Mass Transported Deposit.

Figure 12: Pore water geochemistry results: Total alkalinity and methane concentrations.

Figure 13: High-Resolution 72 traces seismic line (location in Fig. 4) showing contourite moats above the Miocene buried headscarp and associated elongated drifts. Detail A focuses on several truncations forming successive contourite moats. Detail $B$ focuses on the body of associated elongated drifts. Notice that fossil pockmarks are observed within the body of the drifts and that further sediment waves develop on top of them.

\section{References}

Amante, C. and B.W. Eakins, 2009. ETOPO1 1 Arc-Minute Global Relief Model: Procedures, Data Sources and Analysis. NOAA Technical Memorandum NESDIS NGDC-24. National Geophysical Data Center, NOAA. doi:10.7289/V5C8276M [access date].

Basile, C., Mascle, J., Benkhelil, J. and Bouillin, J.-P., 1998. Geodynamic Evolution of the Côte d'Ivoire-Ghana Transform Margin : an overview of leg 159 results. Proceedings of The Ocean Drilling Program, Scientific Results, 159.

Basile, C. and Allemand, P., 2002. Erosion and flexural uplift along transform faults. Geophysical Journal International, Blackwell Science Ltd, 2002, 151, 646-653 
Basile, C., Maillard, A., Patriat, M., Gaullier, V., Loncke, L., Roest, W., Mercier de Lépinay, M. and Pattier, F., 2013. Structure and evolution of the Demerara Plateau, offshore French Guiana: Rifting, tectonic inversion and post-rift tilting at transformdivergent margins intersection. Tectonophysics, Basin Dynamics, 2013, 591, 16-29

Ben-Avraham, Z., Hartnady, C. J. H. and Kitchin, K. A., 1997. Structure and tectonics of the Agulhas-Falkland fracture zone. Tectonophysics, 1997, 282, 83-98

Berndt, C., Mjelde, R., Planke, S., Shimamura, H. and Faleide, J. I., 2001. Controls on the tectono-magmatic evolution of a volcanic transform margin : the Vøring Transform margin.. Marine Geophysical Researches, 2001, 22, 133-152

Dailly P., Henderson T., Hudgens E., Kanschat K. \& P. Lowry, 2012. Exploration for Cretaceous stratigraphic traps in the Gulf of Guinea, West Africa and the discovery of the Jubilee Field: a play opening discovery in the Tano Basin, Offshore Ghana. The Geological society of London, special publication, 369, first published online July 31, 2012, doi: 10.1144/SP369.12,

De Caprona, G. C., 1992. The continental margin of western Côte d'Ivoire: structural framework inherited from intra-continental shearing. Göteborg Universitet, Geologiska Institutionen, 1992, 150pp.

Flemming B.W., 1980. Sand transport and bedform patterns on the continental shelf between Durban and Port Elizabeth (Southest African continental margin). Sedimentary Geology, 26, 179-205.

Flower, B.P., \& Kennet, J., 1994. The Middle Miocene climatic transition: east Antarctic ice sheet development, deep ocean circulation and global carbon cycling. Palaeogeography, Palaeoclimatology, Palaeoecology, 108, p. 537-555.

Gaullier, V., Loncke, L., Droz, L., Basile, C., Maillard, A., Patriat, M., Roest, W.R., Loubrieu, B., Folens, L., Carol, F., 2010. Slope Instability on the French Guiana Transform Margin from Swath-Bathymetry and $3.5 \mathrm{kHz}$ Echograms, in: Mosher, D., Shipp, R., Moscardelli, L., Chaytor, J., Baxter, C.D.P., Lee, H.J., Urgeles, R. (Eds.), Submarine Mass Movements and Their Consequences, Advances in Natural and Technological Hazards Research. Springer, pp. 569 - 579.

Gouyet, S., 1988. Évolution tectono-sédimentaire des marges guyanaise et nord-brésilienne au cours de l'évolution de l'Atlantique Sud. Université de Pau et des pays de l'Adour, 1988, 374pp.

Greenroyd, C. J., Peirce, C., Rodger, M., Watts, A. B. \& Hobbs, R. W., 2007. Crustal structure of the French Guiana margin, West Equatorial Atlantic. Geophysical Journal International, 2007, 169, 964-987.

Greenroyd, C. J., Peirce, C., Rodger, M., Watts, A. B. and Hobbs, R. W., 2008a. Demerara Plateau- the structure and evolution of a transform passive margin. Geophysical Journal International, 2008, 172, 549-564.

Greenroyd, C.J., Peirce, C., Rodger, M., Watts, A.B., Hobbs, R.W., 2008b. Do fracture zones define continental margin segmentation? - Evidence from the French Guiana margin. Earth Planet. Sci. Lett. 272, 553-566. doi:10.1016/j.epsl.2008.05.022

Harmon, N., D. W. Forsyth, R. Lamm, and S. C. Webb, 2007. P and S wave delays beneath intraplate volcanic ridges and gravity lineations near the East Pacific Rise, J. Geophys. Res., 112, B03309, doi:10.1029/2006JB004392. 
Harry, D., Londono, J. and Huerta, A., 2003. Early Paleozoic transform-margin structure beneath the Mississippi coastal plain, southeast United States. Geology, 2003, 31, 969-972.

Ingram, W.C., Mosher, D.C., \& Wise, S.W.J., 2011. Biostratigraphy of an upper Miocene mass-transport deposit on Demerara Rise, northern South American margin, in Masstransport Deposits in Deepwater Settings, Shipp, C., Weimer, P, \& Posamentier, H, p. 475498.

Johns, W.E., Fratantoni, D.M., Zantopp, R.J., 1993. Deep western boundary current variability off northeastern Brazil. Deep-Sea Res, I 40, 293-310.

Klitgord, K.D., \& Schouten, H., 1986. Plate kinematics of the central Atlantic, in Vogt, P.R. \& Tucholke, B.E. eds., The Western North Atlantic Region, Geological Society of America, Boulder, p. 351-378.

Kuijpers A., Werner F., and J. Rumohr, 1993. Sandwaves and other large-scale bedforms as indicators of non-tidal surge currents in the Skagerrak off Northern Denmark. Marine Geology, 111, 209-221.

Larsen, H.C., Saunders, A.D., Clift, P.D., et al., 1994. Seven Million Years of Glaciation in Greenland. Science, v. 264, no. 5161, p. 952-955.

Loncke, L., Droz, L., Gaullier, V., Basile, C., Patriat, M. and Roest, W. R, 2009. Slope instabilities from echo-character mapping along the French Guiana transform margin and Demerara abyssal plain. Marine and Petroleum Geology, 2009, 26, 711-723

Lorenzo, J. M., Mutter, J. C., Larson, R. L. and Group, N. A. S., 1991. Development of the continent-ocean transform boundary of the southern Exmouth Plateau. Geology, 1991, 19, 843-846

Lorenzo, J. M. and Wessel, P., 1997. Flexure across a continent-ocean fracture zone: the northern Falkland/Malvinas Plateau, South Atlantic. Geo-Marine Letters, 1997, 17, 110-118

Mascle, J. and Blarez, E., 1987. Evidence for transform margin evolution from the Ivory Coast-Ghana continental margin. Nature, 1987, 326, 378-381.

Mascle J. \& Basile C., 1998. Le point sur les marges continentales transformantes. C.R. Acad. Sci. Paris, 326, 827-838.

Mascle, J., Lohmann, G.P., \& Moullade, M., 1998. Proceedings of the Ocean Drilling Program, Scientific Results: v. 159: College Station, TX (Ocean Drilling Program), Eds., 1998, doi: doi:10.2973/odp.proc.sr.159.1998.

Mercier de Lepinay, M., Basile, C., Roest, W.R., Patriat, M., Loncke, L., Gaullier, V., Maillard, A., \& De Clarens, P., 2012. Global inventory of transform continental margins: physiographic attributes and controlling parameters, in Brisbane, Australia.

Mercier de Lépinay M., Loncke L., Basile C., Roest W., Patriat M., Maillard A., DeClarens P., in revision. Transform continental margins - Part 2: A worldwide inventory. Submitted to Tectonophysics, july 2014 - accepted in december 2014, with major revisions.

Moran, K., Backman, J., Brinkhuis, H., Clemens, S.C., Cronin, T., Dickens, G.R., Eynaud, F., Gattacceca, J., Jakobsson, M., Jordan, R.W., Kaminski, M., King, J., Koc, N., Krylov, A., et al., 2006. The Cenozoic palaeoenvironment of the Arctic Ocean. Nature, v. 441, no. 7093, p. 601-5, doi: 10.1038/nature04800. 
Mosher, D.C., Erbacher, J., Malone, M.J., 2007. Proceedings of the Ocean Drilling Program, Scientific Results 207 : College Station, TX (Ocean Drilling Program).

Muller, D.., Hodell, D.A., \& Ciesielski, P.F., 1991. Late Miocene to earliest Pliocene paleoceanography of the subAntarctic southeast Atlantic: Stable isotopic sedimentologic and microfossil evidence. Proceedings of the Ocean Drilling Program Scientific Results, $v$. 114 , p. $459-474$.

Parker R. L., 1972. The Rapid Calculation of Potential Anomalies. Geoplzys. J. R. astr. SOC. (1972) 31, 447455.

Pattier, F., Loncke, L., Gaullier, V., Basile, C., Maillard, A., Imbert, P., Roest, W., Vendeville, B., Patriat, M. and Loubrieu, B., 2013. Mass-transport deposits and fluid venting in a transform margin setting, the eastern Demerara Plateau (French Guiana). Marine and Petroleum Geology, 2013, 46, 287-303.

Pilcher, R., Argent, J., 2007. Mega-pockmarks and linear pockmark trains on the West African continental margin. Mar. Geol. 244, 15-32. doi:10.1016/j.margeo.2007.05.002.

Pujos, M., \& Froidefond, J., 1995. Water masses and suspended matter circulation on the French Guiana continental shelf. Continental Shelf Research, v. 15, no. 9, p. 1157-1171.

Rebesco, M., Hernandez-Molina J., Van Rooij D., A. Wahlin, 2014. Contourites and associated sediments controlled by deep-water circulation processes: State-of-the-art and future considerations. Marine Geology, 352, 111-154.

Reid, I., 1988. Crustal Structure beneath the southern Grand Banks :seismic refraction results and their implications. Canadian Journal of Earth Science, 1988, 25, 760-772

Reid, I. and Jackson, H. R., 1997. Crustal structure of northern Baffin Bay: Seismic refraction results and tectonic implications. J. Geophys. Res., 1997, 102, 523-542.

Ryan, W.B.F., S.M. Carbotte, J.O. Coplan, S. O'Hara, A. Melkonian, R. Arko, R.A. Weissel, V. Ferrini, A. Goodwillie, F. Nitsche, J. Bonczkowski, and R. Zemsky, 2009. Global MultiResolution Topography synthesis. Geochem. Geophys. Geosyst., 10, Q03014, doi:10.1029/2008GC002332.

Sage, F., Basile, C., Mascle, J., Pontoise, B. and Whitmarsh, R. B., 2000. Crustal structure of the continent-ocean transition off the Côte d'Ivoire-Ghana transform margin: implications for thermal exchanges across the palaeotransform boundary. Geophysical Journal International, 2000, 143, 662-678.

Sandwell, D. T. \& Smith, W. H. F., 2009. Global marine gravity from retracked Geosat and ERS-1 altimetry: Ridge Segmentation versus spreading rate. J. Geophys. Res., 2009, 114, B01411.

Sandwell, D. T., R. D. Müller, W. H. F. Smith, E. Garcia, R. Francis, 2014. New global marine gravity model from CryoSat-2 and Jason-1 reveals buried tectonic structure. Science, 346, 6205, pp. 65-67.

Seeberg-Elverfeldt, J., Schlüter, M., Feseker, T., Kölling, M., 2005. Rhizon sampling of porewaters near the sediment-water interface of aquatic systems. Limnol. Oceanogr. Methods 3, 2005, 361-37 
Seranne, M., 1999. Early Oligocene stratigraphic turnover on the west Africa continental margin: a signature of the Tertiary greenhouse-to-icehouse transition ? Terra Nova 11, 135140.

Unternehr, P., Curie, D., Olivet, J.L., Goslin, J., \& Beuzart, P., 1988. South Atlantic fits and intraplate boundaries in Africa and South America. Tectonophysics, v. 155, no. 1-4, p. 169 - 179, doi: 10.1016/0040-1951(88)90264-8.

Vågnes, E., 1997. Uplift at thermo-mechanically coupled ocean-continent transforms: Modeled at the Senja Fracture Zone, southwestern Barents Sea. Geo-Marine Letters, 1997, 17,100-109.

Van Rooij D., De Mol B., Huvenne V., Ivanov M., JP Henriet, 2003. Seismic evidence of current-controlled sedimentation in the Belgica mound province, upper Porcupine slope, southwest of Ireland. Marine Geology 195, 31-53.

Werner F., Unsold G., Koopmann B. and A. Stefanon, 1980. Field observations and flume experiments on the nature of comet marks. Sedimentary Geology, 26, 233-262. 